\title{
Social media management as optimization of tourism potential in Osing Kemiren, Banyuwangi Regency
}

\author{
Nur Hadi*, Elya Kurniawati \& Prawinda Putri Anzari \\ Universitas Negeri Malang, Malang City, Indonesia
}

\begin{abstract}
This study aims to increase the tourism potential in Osing Kemiren Village, Banyuwangi Regency. Increasing tourism potential is carried out in two ways, namely (1) increasing knowledge and skills in managing social media accounts, and (2) increasing knowledge and skills in operating social media accounts. Changing society's pattern in socializing demands the community's readiness to carry out the promotion process. The low level of community knowledge and skills in managing social accounts is the reason for this mentoring process. This community service activity is carried out through assistance with the RPA (participatory rural appraisal) approach and the AIDA (Attention, Interest, Desire, Action) model. Through this activity the community is trained to optimize the tourism potential of the Osing tribe in the traditional village of Kemiren. In order to that, the tourism potential and all tourism supporting sectors in the Osing Traditional Village increase and impact the welfare of the surrounding community.
\end{abstract}

Keywords: Management, social media, travel, Osing.

\section{INTRODUCTION}

The modernization of lifestyle has resulted in the formation of different patterns of action. Modern society today is very dependent on the existence of the internet. The public uses this technology in carrying out their activities, including the use of social media accounts such as Instagram, WhatsApp, Facebook, Twitter, etc. The internet has had many impacts on the way humans communicate, exchange information and improve their economy (Febriyantoro \& Arisandi 2018). The life of a community such as the Osing community in Banyuwangi Regency has also been affected by the existing social changes (Made Pidata 2009)

The Kemiren Traditional Village is one of the Osing traditional community villages located in Banyuwangi Regency (Kabupaten Banyuwangi no date). It is one of the leading tourism destinations in Banyuwangi Regency. Emphasizing the excellence of this community in the eyes of the world is very important. Every year, the Banyuwangi Government organizes various cultural and tourism events to promote and preserve local culture (Banyuwangi (Jawa Timur 2015). The advantages and existing events will be more developed with the presence of social media accounts. Social account management and management can be done by empowering the surrounding community. Community empowerment with these activities will further optimize the potential of the Osing Tribe Village and Tourism.

Empowerment is a way so that people, communities, and organizations are directed to control or rule over their lives (Lucchetti \& Font 2013). There are five factors driving change in society: (1) levels of need, (2) direct benefits, (3) competition, (4) rewards or penalties, and (5) items and novelty. As an effort to adapt to the various changes that occur in cultural elements, to get a new balance in the order of social life, individuals as members of the community concerned can

*Corresponding author: nur.hadi.fis@um.ac.id 
carry out various reinterpretations of the cultural elements they have. Reinterpretation can occur in aspects of appearance, meaning, benefits, and aspects of particular cultural element's function (Mardikanto \& Soebianto 2012).

This Community Service is carried out as an effort to increase understanding and skills for youth as the target group in developing tourism so that the hope is that the village will become a highly competitive community (Agung 2018). The approach is carried out based on participatory rural appraisal (PRA), which means basing the needs of the villagers, and they are active in the implementation of the training. The AIDA model will be used in conducting the training, namely Attention, Interest, Desire, Action to foster participant motivation and training effectiveness. We hope that with the PRA model of community-based empowerment activities, in social account management training, optimization of the Osing tribe tourism in Kemiren Village will be better improved.

Based on the analysis of the situation, this study formulates the following problems as follows: (1) how are the upgraded operational knowledge and skills about social account management used to optimize potential village Osing Kemiren tours in Banyuwangi Regency and (2) how to increase knowledge and skills in operating social accounts to optimize village Osing Kemiren tours in Banyuwangi Regency.

\section{METHOD}

This study used method of increasing knowledge and skills in the form of training to solve problems experienced by the Osing community. The target group is the Kemiren traditional village apparatus and village youth totaling 40 people. Community service was carried out using the RPA (participatory rural appraisal) approach, meaning that they base villagers' needs, and they are active in the implementation of the training. This training activity used the AIDA model, namely Attention, Interest, Desire, Action. With this approach, this activity's method is carried out by means of the creation, operation and training of creating social accounts for optimization village potential Osing tribe tour in the Village Kemiren could be improved. The activities carried out are lectures, questions and answers, discussions, demonstrations, training, and assignments. In supporting the success of this activity, several methods are used, including: (1) observation methods; (2) the question and answer method; (3) discussion method; (4) practical approach; (5) demonstration method.

\section{RESULT AND DISCUSSION}

Osing is a traditional community located in Kemiren Village, Banyuwangi Regency. The word Kemiren comes from the number of candlenuts, durian and palm trees in the history of the area's formation. The development of time made POKDARWIS spark Kemiren as an abbreviation of Kemroyok Mikul Rencana Nyata (gotong-royong), which is also the principle of community life. This traditional tourism village was formed because Kemiren has many unique customs, arts, culture, lifestyle, culinary delights that have been preserved for a long time(Profil desa Kemiren - Desa Kemiren Banyuwangi, Desa Adat Kemiren, Desa wisata Osing Kemiren, no date). Various events were held to promote Osing in local and international communities (Sumarmi et al. 2020).

Promotion is the spearhead of the development of the tourism sector and the regional economy. The result of promotional media in the digital era has made social media a very effective means. It is because $56 \%$ of the Indonesian population is an active user of social media. As many as $48 \%$ of them actively access their social media through their cellphones. This phenomenon shows that modern society is indeed attached to social media and gadgets. Because of technological development, distance is not an obstacle to conveying information from one place to another. moreover, technology makes us into the new reality, compression, reduction, compaction and acceleration which makes everything close, small and not limited to distance (Piliang 1998). Social 
media can be a means to explore tourism potential in Kemiren so that it attracts the attention of foreign and local tourists.

The use of social media as a means of promotion should pay attention to trends in society. The social media platforms that are actively used by Indonesians are reflected in figure 2. People tend to use the internet to open YouTube (88\%), WhatsApp (83\%), Facebook (81\%), Instagram (80\%) and line $(59 \%)$. As service or product providers who want to carry out a promotional activity, we should consider the available options (Websindo 2019).

Ironically, when the world's development demands mastery of technology, it turns out that not all human resources know how to control it. In the case of the Osing tribe, for example, not all levels of society, business actors, or traditional and tourism activists have the ability to operate social media accounts. Meanwhile, on the other hand, they should have the ability to manage social media accounts to promote. It is clear why, in the end, people need to increase their knowledge and skills. So that in the formulation of general development policies, Banyuwangi Regency states that from the perspective of government institutions, it seeks to make efforts to improve performance through improving human resources (RJPMD Kabupaten Banyuwangi 2019-2024 2019).

One way to improve performance and improve the quality of human resources is by empowering the surrounding community. Empowerment is a way that people, communities, and organizations are directed to control or rule over their lives (Sembiring et al. 2019). A community's life basically undergoes social changes, both big and small, slow and fast, and this includes the Osing community in Banyuwangi Regency. Every society's life journey is dynamic, always experiencing social transformation, both traditional and modern (Made Pidata 2009). The emergence of socio-cultural changes can occur due to the influence of internal factors that arise from the dynamics of the life of the people supporting the culture itself, or effects that come from outside (Sairin 2002).

\subsection{Increased operational knowledge and skills about social account management}

Providing operational knowledge and skills on social account management to target groups is carried out to optimize the tourism potential of the Osing community in Kemiren Village, Banyuwangi Regency. This demand was born because of changes in consumer patterns in the current millennial era. 2012 data shows that in searching for information, 52\% of consumers are search engine users. This choice is made because search engines provide more relevant and useful results. Only $7 \%$ felt that the results were less relevant. Digital media is one of the media that becomes a reference for the community to get information (Mansur \& Adnan 2018). Like when people want to get information about the Osing Tribe, Kemiren Village, or Banyuwangi, consumers will search the website www.osingbanyuwangi.com (Osing Banyuwangi, no date) or other social media that provides this information. As a service provider or product related to the potential of Osing, it must be adaptive by making changes in sharing existing information. Changes in people's lifestyles in using the internet to search for information require increased knowledge and skills (Kurniawati et al. 2019). Lifestyle becomes a feature of a modern world through development or modernization, which causes the formation of various patterns of action that differentiate one person from another, or a group from another group (Chaney 2006).

The Osing community must master technology skills such as social media accounts to get accepted today. The results of field observations indicate that the availability of available resources is even in dire need of processing and marketing through online media. The development of the idea (brainstorming) is the availability of resources at the service location to enable digital marketing training to be carried out. Multimedia-based training media in the form of videos and hands-on practice using cell phone facilities to process promotional media. In its implementation, the training is categorized into two stages with different periods, including:

a. Practice method. This method involves activities between the implementing team and the target group to create, apply and operate the activity aspects' components correctly to achieve maximum results. This training is carried out through installing simple network infrastructure, creating an 
account (for those who don't have a Facebook and Instagram account), and digital product marketing.

b. Demonstration method. The participants use this method to show concrete clarity about the theory and steps for operational, post-operational preparation, and results. At this stage, participants: (1) take and process images independently (2) practice the material and experiences (3) the abilities are then monitored from their respective posts on their social media to see their capabilities in promoting the product from the production stage to being presented on social media pages such as Instagram or Facebook. Through this media, besides getting direct experience in delivering products to consumers, participants also understand how to attract potential buyers. Through uploads on the participants' social media accounts, the wider community can see firsthand the goods produced independently by the Osing community.

\subsection{Group empowerment in increasing knowledge and skills in an implementation}

Empowering the target group to have knowledge and skills in an implementation manner is carried out so that the community can operate social accounts to optimize the Osing Traditional Village's tourism potential in Kemiren Village, Banyuwangi Regency. Conceptually, community empowerment is an effort to increase the dignity of layers who are currently unable to escape the traps of poverty and underdevelopment. In other words, empowering is enabling and independent community (Al Siddiq et al. 2020). Cultural dynamics that technological advances have caused through the process of development or modernization have also been able to change the idealization of humans that have resulted in mass culture, consumerism and ecstatic culture of life (Subandy 1997).

There are five factors driving change in society: (1) levels of need, (2) direct benefits, (3) competition, (4) rewards or penalties, and (5) items and novelty. As an effort to adapt to the various changes that occur in cultural elements, to get a new balance in the order of social life, individuals as members of the community concerned can carry out various reinterpretations of the cultural elements they have. Reinterpretation can occur in aspects of appearance, meaning, benefits and aspects of a particular cultural element's function (Mardikanto \& Soebianto 2012).

The Osing tribe has a very potential and adaptive society in facing social change. The existing community is divided into several active working groups such as BUMDES, POKDARWIS, Karang Taruna, and UMKM. The members of each community group are actively involved in the training given. They focus on the potential that can be explored in each field. Some of them also work in synergies, such as the synergy between BUMDES and Karang Taruna in the management of Warung Kemangi, art shop, and Kemiren screen printing. The collaboration between BUMDES and POKDARWIS is carried out in managing tour package providers, managing art studios and cultural festival activities, and homestays. On the other hand, there are MSME players who focus on developing "Jaran Goyang" coffee which is the mainstay of the Osing Tribe.

\section{CONCLUSION}

In the Osing tribe, not all levels of society, business actors, or traditional and tourism activists can operate social media accounts. Meanwhile, on the other hand, they should have the ability to manage social media accounts for promotion. This community service was made to solve resource problems in the Osing tribe. In the first stage, the team provides operational knowledge and skills on social account management. This training is carried out through installing simple network infrastructure, creating an account (a Facebook and Instagram account) and digital product marketing. Furthermore, in the second stage, the team empowers the target group to have knowledge and skills in an implementation manner. The effect is that the community can operate social accounts to optimize the Osing Traditional Village's tourism potential in Kemiren Village, Banyuwangi Regency. 


\section{REFERENCES}

Agung (2018) Pengembangan Desa Wisata untuk Kesejahteraan Masyarakat | Universitas Gadjah Mada. Available at: https://ugm.ac.id/id/berita/15939-pengembangan.desa.wisata.untuk. kesejahteraan.masyarakat.

Banyuwangi (Jawa Timur, I. C. and T. S. (2015) Banyuwangi, the New Paradise of Indonesian Tourism?: Visitor's Guide Book. Banyuwangi Regency Culture and Tourism Service. Available at: https://books.google.co.id/books?id=RqLDDAEACAAJ.

Chaney, D. (2006) 'Life Styles Sebuah Pengantar Komprehensif (terjemahan)', Yogyakarta: Jalasutra.

Febriyantoro, M. T. and Arisandi, D. (2018) 'Pemanfaatan Digital Marketing Bagi Usaha Mikro, Kecil Dan Menengah Pada Era Masyarakat Ekonomi Asean', JMD: Jurnal Riset Manajemen \& Bisnis Dewantara. doi: $10.26533 /$ jmd.v1i2.175.

Kabupaten Banyuwangi (no date). Available at: https://banyuwangikab.go.id/.

Kurniawati, E., Chrissendy, M. and Saputra, D. (2019) '93 Behavioral factor influencing indonesian micro, small and medium (msme's) owners decision-making in adopting e-commerce', Journal of Entrepreneurship, Business and Economics.

Lucchetti, V. G. and Font, X. (2013) 'Community based tourism: critical success factors.', ICRT occasional paper, (OP27).

Made Pidata (2009) 'Landasan Kependidikan Stimulus Ilmu Pendidikan Bercorak Indonesia', in Jakarta: Rineka Cipta.

Mansur, N. K. and Adnan, F. (2018) 'Search engine optimization: Raising the ranking of Suku Osing websites on search engine page', in Proceedings of the 2017 4th International Conference on Computer Applications and Information Processing Technology, CAIPT 2017. doi: 10.1109/CAIPT.2017.8320731.

Mardikanto, T. and Soebianto, P. (2012) Pemberdayaan masyarakat dalam perspektif kebijakan publik. Alfabeta.

Osing Banyuwangi (no date). Available at: www.osingbayuwangi.com.

Piliang, Y. A. (1998) Sebuah dunia yang dilipat: Realitas kebudayaan menjelang milenium ketiga dan matinya posmodernisme. Mizan Pustaka.

Profil desa Kemiren - Desa Kemiren Banyuwangi, Desa Adat Kemiren, Desa wisata Osing Kemiren (no date). Available at: https://kemiren.com/tentang-desa-kemiren/ (Accessed: 1 February 2021).

RJPMD Kabupaten Banyuwangi $2019-2024$ (2019). Available at: http://bappeda.jatimprov.go.id/bappeda/ wp-content/uploads/dokren/rancangan_awal_rpjmd_jatim_2019_20 24.pdf.

Sairin, S. (2002) Perubahan Sosial Masyarakat Indonesia: Perspektif Antropologi. Pustaka Pelajar.

Sembiring, E. B. et al. (2019) 'Pemberdayaan Masyarakat Kampung Rempang Cate Melalui Pelatihan Pemasaran Digital untuk Produk Unggulan Pasir Panjang', JURNAL PENGABDIAN MASYARAKAT (AbdiMas), 1(2), pp. 104-117.

Al Siddiq, I. H. et al. (2020) 'Encouraging Economic Development Through Local Community Participation in Sidoarjo, Indonesia', in. doi: 10.2991/assehr.k.200214.022.

Subandy, I. (1997) 'Ecstasy Gaya Hidup: Kebudayaan Pop dalam “Masyarakat Komoditas” Indonesia', Bandung: Mizan Pustaka.

Sumarmi et al. (2020) 'Cultural ecology of osing in development of Kemiren Tourist Village as international tourist attraction', in IOP Conference Series: Earth and Environmental Science. doi: 10.1088/1755$1315 / 485 / 1 / 012017$.

Websindo (2019) Indonesia Digital 2019?: Media Sosial, Websindo. 